\title{
Penerapan Social Network Analysis dengan Menggunakan Metode Sociomatrix pada Akun Instagram Siswa SMA di Surabaya
}

\author{
${ }^{1}$ Nur Aini Rakhmawati, ${ }^{2}$ Rheindra Alfarhizi, ${ }^{3}$ Irmasari Hafidz \\ ${ }^{1,2,3}$ Departemen Sistem Informasi, Fakultas Teknologi Elektro dan Informatika Cerdas, \\ Institut Teknologi Sepuluh Nopember Surabaya \\ Email: nur.aini@is.its.ac.id,rheindra14@mhs.is.its.ac.id, irma@is.its.ac.id ,
}

(Diterima: 27 Februari 2020,direvisi: 7 Mei 2020, disetujui:12 Mei 2020 )

\begin{abstract}
This study observes the relationships of the Instagram accounts of high school students in Surabaya using sociomatrix in Social Network Analysis. We found eighteen groups are consisting of one biggest sociogram and seven smaller sociograms based on a survey from 18 high schools in Surabaya. The largest sociogram consists of 12 high schools. The biggest node is a high school student of SMAN 7 Surabaya with 22 Instagram friends who follow each other. The strongest friendships is also found from SMAN 7 Surabaya high school, with total the same 360 account of followings and followers and the highest links valued at 6.0. The number of friendships between female students (289 connections) is approximately 2.5 times higher than the friendship between males student (115 connections). Besides, the friendships between females students are about the same number of the connections from the opposites sex (284 female-male connections or links)
\end{abstract}

Keywords: Instagram, Senior High School Student, Social Network Analysis, Sociomatrix, Sociogram, Visualization

\begin{abstract}
ABSTRAK
Penelitian ini memetakan bentuk hubungan berdasarkan media sosial Instagram pelajar Sekolah Menengah Atas (SMA) di Surabaya dengan menggunakan socimatrix yang merupakan bagian dari Social Network Analysis. Hasil penelitian ini memetakan 18 kelompok berdasarkan 18 SMA di Surabaya, terdiri dari 1 sociogram besar dan 7 sociogram kecil, dimana setiap kelompok rata-rata berasal dari sekolah (SMA) yang sama. Sociogram besar terdiri dari 12 SMA. Akun yang paling dikenal oleh teman sekitarnya atau node terbesar berasal dari SMAN 7 Surabaya dengan 22 teman yang saling follow dengannya. Adapun akun yang memiliki pertemanan yang kuat atau link tertebal berasal dari SMAN 7 Surabaya dengan jumlah kesamaan followings dan followers sebanyak 360 akun atau senilai 6.00 pada link yang terbentuk. Pertemanan antar siswa perempuan (289) memiliki jumlah 2,5 kali dari jumlah pertemanan antar siswa laki-laki (115) dan pertemanan antar siswa perempuan memiliki jumlah hampir yang sama dengan pertemanan lawan jenis (284).
\end{abstract}

Kata Kunci: Instagram, Pola Hubungan, Siswa SMA, Social Network Analysis, Sociomatrix, Sociogram, Visualisasi.

\section{PENDAHULUAN}

Pesatnya pertumbuhan media sosial di kalangan remaja membuat pola pertemanan tidak memiliki batas. Media sosial memberikan ruang eksplorasi bentuk pertemanan dengan cara membagikan setiap bentuk momen berupa foto maupun video dan tidak berbatas waktu. Sejumlah 18,4 persen dari 132,7 juta pengguna aktif internet di Indonesia merupakan remaja [1]. Instagram menjadi sorotan karena memiliki peningkatan terbesar dari segi jumlah pengguna aktif [2] dengan menempati peringkat ke-4 sejak Oktober 2010 dalam penggunaan aktif media sosial [3].

Memanfaatkan konektivitas antara pertemanan, informasi, uang, dan kekuatan, Social Network Analysis menghubungkan beberapa faktor dengan apa yang kita pikirkan, apa yang kita tahu, dan apa yang kita perbuat [4]. Pola pertemanan digunakan sebagai data utama untuk mencari bentuk kedekatan antar akun pada media sosial Instagram diukur menggunakan sociomatrix [4]. Sociomatrix

Rakhmawati, Penerapan Social Network Analysis dengan Menggunakan Metode Sociomatrix pada Akun Instagram Siswa SMA di Surabaya 
membantu memetakan atau membuat pola hubungan antar akun berdasarkan data followings dan followers. Komponen utama berupa matrix node dan matrix link sebagai hasil dari sociomatrix untuk proses visualisasi.

Pada penelitian sebelumnya kami menganalisa waktu yang dihabiskan remaja di Instagram [5]. Penggunaan Social Network Analysis pada Instagram telah dilakukan oleh [6][7][8]. Penelitian ini dikhususkan untuk menganalisa hubungan sosial yang terbentuk dari siswa Sekolah Menengah Atas (SMA) dari 18 SMA yang ada di Surabaya, yang menjadi target dari mata kuliah Etika Profesi di Jurusan Sistem Informasi Institut Teknologi Sepuluh Nopember Surabaya. Tujuan dari penelitian ini adalah mengetahui pola hubungan siswa pada media sosial Instagram siswa SMA (high school student) menggunakan sociomatrix dengan visualisasi berupa force-directed graph menggunakan library javascript D3js.

\section{TINJAUAN PUSTAKA}

Social Science berfokus pada struktur, misalnya struktur dari sekelompok manusia, komunitas, organisasi, pasar, sosial, atau dunia maya [9]. Struktur sosial inilah yang menjadi dasar dari sebuah hubungan sosial yang terbentuk (network of social ties). Social Network Analysis menganggap bahwa hubungan interpersonal itu penting, seperti hubungan antara kedua organisasi atau negara, karena mereka menunjukkan sebuah perilaku, sikap, informasi, atau barang. Social Network Analysis memberikan metodologi untuk menganalisis hubungan sosial melalui beberapa faktor, informasi yang mendukung, dan pola sehingga dapat diukur dan dianalisis. Tujuan utama dari Social Network Analysis adalah mendeteksi dan menafsirkan pola ikatan sosial antar aktor atau individu [9].

Pada teori social network, pentingnya struktur menjadi aspek utama yang mempengaruhi komposisi yang membentuknya. Ilmu kimia menganalogikan social network ini sebagai komposisi dari sebuah unsur kimia, maka analogi dalam suatu hubungan jika memiliki atribut komponen yang berbeda, maka hasil yang terbentuk akan berbeda pula [10].

Sociomatrix merupakan pengukuran penerimaan atau penolakan sosial melalui preferensi yang dinyatakan pada kelompok sosial [11]. Tiap individu (node) dari sebuah kelompok/ pola yang terbentuk memiliki titik tengah (center) dan pinggiran (edge). Sociomatrix dianggap paling menggambarkan sebuah hubungan sosial [9], dan digunakan sebagai alat untuk mengukur pola suatu hubungan sosial berdasarkan matrix tertentu, sehingga kedekatan atau hubungan pertemanan antar individu (node) dapat terukur [12]. Menurut [11], sebuah topologi hubungan Social Network Analysis dapat dibagi menjadi 4 kelompok seperti terlihat pada pada Gambar 1:

1. Similarities (kesamaan atribut) contoh: lokasi, keanggotaan sebuah klub, jenis kelamin,

2. Social Relations (kinship: hubungan kekeluargaan; other roles: teman dari, siswa dari, competitor dari; affective: kesukaan atau ketidaksukaan atas sesuatu; cognitive: tahu tentang, pengetahuan terhadap sesuatu),

3. Interactions (interaksi antar individu),

4. Flows (aliran), contoh: informasi, sumber daya, keyakinan.

Pada penelitian ini, topologi hubungan Social Network Analysis antara akun Instagram dari siswa 18 SMA di Surabaya dikategorikan tipe Social Relation: other role [11], yakni friend of dan/atau student of. Studi ini mencari kedekatan antar siswa SMA yang saling mengikuti (follow) akun Instagram antar satu siswa SMA dengan yang lain.

\begin{tabular}{|c|c|c|c|c|c|c|c|c|}
\hline \multicolumn{3}{|c|}{ Similarities } & \multicolumn{4}{|c|}{ Social Relations } & Interactions & Flows \\
\hline $\begin{array}{l}\text { Location } \\
\text { e.g., } \\
\text { Same } \\
\text { spatial } \\
\text { and } \\
\text { temporal } \\
\text { space }\end{array}$ & $\begin{array}{c}\text { Membership } \\
\text { e.g., } \\
\text { Same } \\
\text { clubs } \\
\text { Same } \\
\text { events } \\
\text { etc. }\end{array}$ & $\begin{array}{l}\text { Attribute } \\
\text { e.g., } \\
\text { Same } \\
\text { gender } \\
\text { Same } \\
\text { attitude } \\
\text { etc. }\end{array}$ & $\begin{array}{c}\text { Kinship } \\
\text { e.g., } \\
\text { Mother of } \\
\text { Sibling of }\end{array}$ & $\begin{array}{c}\text { Other role } \\
\text { e.g., } \\
\text { Friend of } \\
\text { Boss of } \\
\text { Student of } \\
\text { Competitor of }\end{array}$ & $\begin{array}{c}\text { Affective } \\
\text { e.g., } \\
\text { Likes } \\
\text { Hates } \\
\text { etc. }\end{array}$ & $\begin{array}{c}\text { Cognitive } \\
\text { e.g., } \\
\text { Knows } \\
\text { Knows } \\
\text { about } \\
\text { Sees as } \\
\text { happy } \\
\text { etc. }\end{array}$ & $\begin{array}{c}\text { e.g., } \\
\text { Sex with } \\
\text { Talked to } \\
\text { Advice to } \\
\text { Helped } \\
\text { Harmed } \\
\text { etc. }\end{array}$ & $\begin{array}{c}\text { e.g., } \\
\text { Information } \\
\text { Beliefs } \\
\text { Personnel } \\
\text { Resources } \\
\text { etc. }\end{array}$ \\
\hline
\end{tabular}

Gambar 1 Topologi hubungan dalam social network analysis [11] 


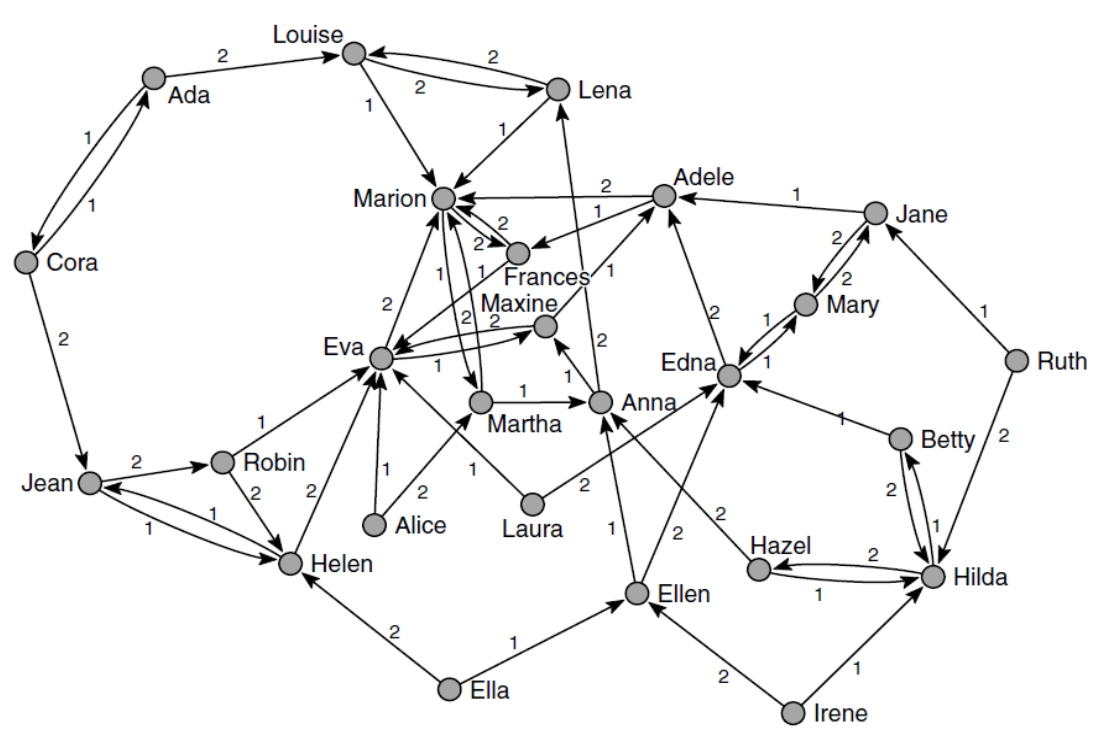

\section{Gambar 2 Sociogram pada kasus dinner table [12]}

Sociogram merupakan bentuk visualisasi berupa graf dari individu (nodes) dan penghubung (links) yang menggambarkan sebuah hubungan antar node (individu) dan membentuk sebuah jaringjaring (seperti pada Gambar 2) berdasarkan data banyak individu dari sebuah sociomatrix. Visualisasi sociogram pada penelitian ini menggunakan visualisasi force-directed graph dengan menggunakan library D3js dari sebuah project di kasus film seri 'Game of Thrones'[13]. Radius node merupakan bentuk pengaruh pada tiap karakter. Rumus node pada studi kasus diadaptasi untuk menyesuaikan bentuk visualisasi, yang dijelaskan pada rumus 1 .

node $=$ size $* 1.5$

Dimana jika size $>5$, maka text $=$ size dan selain itu, text $=5$

Value dipakai untuk menentukan nilai variabel links yang digunakan untuk menyatakan seberapa kuat (strongest link) hubungan yang terbentuk antar node. Nilai links dirumuskan pada rumus 2.

$$
\text { link }=\frac{\text { value }}{100}
$$

\section{METODE PENELITIAN}

Metodologi penelitian, sumber data beserta arsitektur sistem akan dijelaskan pada bagian ini.

\section{A. Sumber Data}

Data yang digunakan dalam penelitian ini adalah data akun media sosial Instagram siswa Sekolah Menengah Atas (SMA) dari 18 SMA yang ada di Surabaya, yang menjadi target dari mata kuliah Etika Profesi di Jurusan Sistem Informasi Institut Teknologi Sepuluh Nopember Surabaya.

\section{B. Arsitektur Sistem}

Gambar 3 menjelaskan arsitektur sistema, dimana menunjukkan proses pemodelan data dari kumpulan akun Instagram ke bentuk sociogram. 


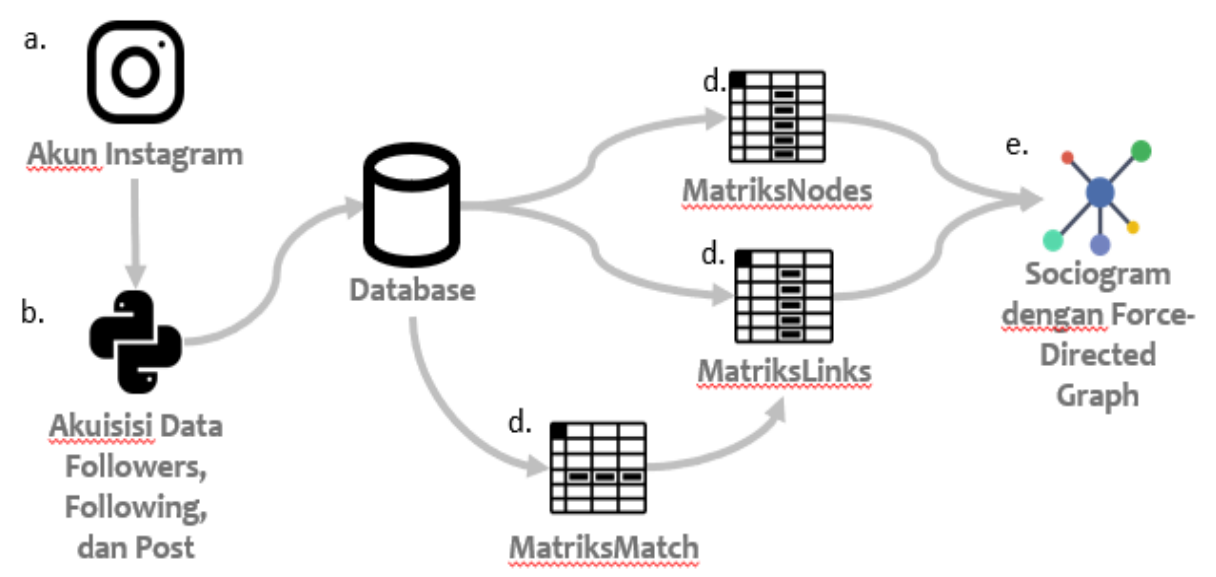

Gambar. 3 Arsitektur sistem

Berikut keterangan Gambar 3 arsitektur sistem:

a. Akun Instagram siswa merupakan komponen data awal yang dipakai dalam penelitian ini berupa username akun Instagram.

- Input: kuesioner sosial media

- Proses: sosialisasi mata kuliah Etika Profesi ke 18 SMA di Surabaya

- Output: Akun Instagram siswa 18 SMA di Surabaya

b. Python sebagai alat akuisisi data dari akun Instagram berupa pengambilan jumlah followings dan followers.

- Input: akun Instagram

- Proses: crawling data followings dan followers berupa JSON

- Output: data followings dan followers setiap username akun Instagram dari siswa

c. Hasil crawling dimasukkan ke database MongoDB.

- Input: data followings, followers, username

- Proses: memasukkan data hasil ke MongoDB

- Output: data followings, followers, dan username berhasil dimasukkan ke MongoDB

d. Matrix merupakan bentuk pengembangan dari sociomatrix.

- Input: tabel/ kumpulan atau collections of followings, followers, username akun Instagram

- Proses: membersihkan data mentah pada database lalu dilakukan manipulasi

- Output: matrix match, matrix links, dan matrix nodes

e. Sociogram sebagai bentuk visualisasi Social Network Analysis

- Input: matrix match, matrix links, dan matrix nodes

- Proses: kodifikasi visual berdasarkan data matrix yang dimiliki

- Output: visualisasi SNA

\section{Tahapan Penelitian}

Berikut adalah tahapan dalam penelitian yang dilakukan untuk Social Network Analysis pada akun media sosial Instagram:

\section{Akuisisi Data}

Proses akuisisi data dimulai setelah mendapatkan daftar akun Instagram siswa SMA dari penelitian atau survey ke 18 SMA di Surabaya. Data yang didapatkan merupakan data followings dan followers di Instagram dalam bentuk JSON dari tiap akun yang terdaftar dengan menggunakan web crawler. Adapun informasi yang dari tiap followings dan followers adalah informasi lengkap dari profil di setiap akun yang terambil, yaitu $p k$ atau id akun, username, full name, status private, url foto profil, id foto profil, verified status, dan beberapa data profil pendukung lain. Data yang diambil pada tahap ini hanya data $p k$ (id akun) dan username.

2. Pembuatan Sociomatrix

Pada tahap ini hasil dari akuisisi data berupa followings dan followers dari akun utama yang terdaftar akan diolah untuk mendapatkan username yang memiliki kesamaan dengan akun 
utama yang terdaftar. Proses ini dilakukan untuk mencari tahu kesamaan aktivitas saling follow antar akun utama Instagram yang terdaftar.

\subsection{Matrix Match}

Hasil dari akuisisi data followings dan followers akan diolah untuk mendapatkan username yang termasuk dalam data followings dan followers. Proses ini dilakukan untuk mencari tahu kesamaan aktivitas saling follow antar akun.

Tabel 1 Bentuk Dasar Matrix Match [4]

\begin{tabular}{lllll}
\hline & $\begin{array}{l}\text { User } \\
\text { name1 }\end{array}$ & $\begin{array}{l}\text { user } \\
\text { name2 }\end{array}$ & $\begin{array}{l}\text { user } \\
\text { name3 }\end{array}$ & $\begin{array}{l}\text { user } \\
\text { nameX }\end{array}$ \\
\hline username1 & - & 1 & 0 & 0 \\
username2 & 1 & - & 1 & 1 \\
username3 & 0 & 1 & - & 0 \\
usernameX & 0 & 1 & 0 & - \\
\hline
\end{tabular}

Nilai pada Tabel 1 menyatakan status hubungan antar akun, nol untuk tidak saling follow dan satu untuk saling follow.

Tabel 2 merupakan bentuk matrix dan akan diubah ke bentuk edge list [12], yaitu 'source node' dan 'target node' sebagai penyempurnaan struktur dari matrix links. Grunspan [4], mendefinisikan sociomatrix dibentuk berdasarkan teman pada kelas sebelumnya dan siswa yang pintar. Pada studi ini, kami mengasumsikan bahwa:

1. teman pada kelas sebelumnya [4]: kami adaptasi dengan definisi sebagai teman yang memiliki kesamaan sekolah atau berasal dari SMA yang sama,

2. siswa yang pintar [4]: kami adaptasi dengan definisi sebagai siswa yang memiliki followers yang banyak atau siswa yang berpotensial menjadi influencer.

Adapun bentuk edge list digambarkan pada Tabel 2.

Tabel 2 Bentuk Edge List pada Matrix Match[11]

\begin{tabular}{cc}
\hline Node1/Source Node & Node2 / Target Node \\
\hline Brian & Derek \\
Derek & Lisa \\
Derek & Brian \\
Lisa & Derek \\
\hline
\end{tabular}

Degree centrality dari sebuah node digunakan untuk mengukur dan mendefinisikan bentuk dari sebuah node, serta menentukan seberapa penting sebuah node tersebut di lingkungannya. Berdasarkan graph theory, nilai degree centrality (atau DC) [14] berupa jumlah hubungan yang dimiliki sebuah nodes source. Berikut rumus untuk menghitung degree centrality (D) :

$$
\sigma_{D}(i)=\sum_{j}^{N} a_{i j}
$$

dimana $i$ adalah node utama atau node source yang akan dihitung dan $j$ adalah node lain yang terhubung, $N$ total node yang ada dan $a$ akan bernilai 1 jika dia saling terhubung, bernilai 0 jika tidak terhubung. Degree centrality juga bermanfaat untuk mengukur popularitas tiap node yang mana semakin tinggi popularitas sebuah node semakin tinggi pula akses ke node lain untuk bertukar informasi. Asumsi yang digunakan di penelitian ini bahwa popularitas atau nilai dari degree centrality $(D)$ tidak menentukan node atau akun tersebut merupakan seorang influencer.

\subsection{Matrix Nodes}

Nodes Collection dibentuk berdasarkan 'username collection' dan field baru berisikan size dari tiap nodes. Ukuran nodes didapatkan dari banyaknya 'id_target' yang terdaftar pada field target Rakhmawati, Penerapan Social Network Analysis dengan Menggunakan Metode Sociomatrix pada Akun Instagram Siswa SMA di Surabaya 
pada nodes collection untuk masing masing 'id_source'. Berikut adalah contoh isi tabel matrix nodes pada Tabel 3.

Tabel 3 Contoh Matrix Nodes

\begin{tabular}{llll}
\hline Pk & username & group & Size \\
\hline 2261593527 & valentino & N02 & 21 \\
224511234 & rossi & N16 & 13 \\
1551256352 & stoner & K10 & 5 \\
\hline
\end{tabular}

Pada kasus matrix nodes Tabel 3 ini, ukuran nodes didapatkan dari banyaknya 'id_target' yang terdaftar pada field target pada nodes collection untuk masing masing 'id source'. Hal ini menandakan seberapa besar network akun Instagram siswa tersebut dalam satu sekolah dan di kalangan SMA Surabaya.

\subsection{Matrix Links}

Matrix links merupakan tabel yang berisikan node source dan node target. Nilai node merupakan hasil dari matrix match pada proses sebelumnya. Kedua node dihubungkan dengan garis untuk menandakan seberapa kuat hubungan yang dimiliki oleh kedua node yang saling terhubung. Garis tersebut yang dinamakan dengan links. Pada Matrix Links atau links collection pada database, nilai penentu dari garis tersebut adalah nilai value. Berikut adalah contoh isi tabel Matrix Links pada Tabel 4.

Tabel 4 Contoh Matrix Links [11]

\begin{tabular}{lll}
\hline Id_source & Id_target & value \\
\hline 2351231 & 1524561 & 12 \\
1524561 & 2351231 & 31 \\
51667222 & 2351231 & 9 \\
\hline
\end{tabular}

Pada penelitian ini, tebal tipis garis menunjukkan seberapa kuat pertemanan kedua node yang saling terhubung. Kesamaan followings dan followers merupakan bobot yang dipakai untuk mengindikasikan tebalnya hubungan antar node, dengan kata lain kedua node tersebut memiliki hubungan keakraban yang kuat jika bergaris tebal.

3. Implementasi Social Network Analysis dengan metode Sociomatrix

Pada tahap ini dilakukan pembentukan matrix nodes dan matrix links dengan metode sociomatrix. Metode ini dimulai dengan memetakan followings dan followers berdasarkan 'pk' akun yang terdaftar untuk membentuk matrix links dan menambahkan kolom value. Nilai value berasal dari kesamaan followings dan followers. Selain kolom value, jenis kelamin merupakan kolom opsional, dan digunakan untuk keperluan pada filtering data pada visualisasi. Matrix nodes berasal dari data username pada database dikonversi menjadi matrix nodes dengan menambahkan kolom size. Nilai size didapatkan dari banyaknya node edge yang terhubung dengan node center atau node utama.

4. Visualisasi Sociogram

Pada tahap ini sociomatrix akan diterjemahkan kedalam bentuk visual dengan menggunakan library D3js yaitu force-directed graph. Visualisasi ini akan menunjukkan hasil berupa node yang saling terhubung oleh link berdasarkan size dan value dari masing masing variable node yang dikategorikan menjadi dua kelompok, berdasarkan asal sekolah dan jenis kelamin dari tiap pemilik node atau akun Instagram.

\section{HASIL DAN PEMBAHASAN}

Pada bagian ini dijelaskan mengenai hasil dari sumber data yang dapat digunakan, dilanjutkan dengan tahap pra-proses data dan pembahasan hasil komponen utama size dan link pada sociomatrix dan sociogram.

Rakhmawati, Penerapan Social Network Analysis dengan Menggunakan Metode Sociomatrix pada Akun Instagram Siswa SMA di Surabaya 


\section{A. Memuat Data}

Berikut hasil pengumpulan data melalui tahap verifikasi dan validasi akun sebelum masuk tahap pra-proses data dalam penelitian ditunjukkan pada Tabel 5.

Tabel 5 Hasil Pengumpulan Data

\begin{tabular}{cc}
\hline Jumlah sekolah & 18 \\
Total Responden & 619 \\
Total Pengguna Aktif Instagram & 464 \\
Akun publik & 160 \\
Akun private & 304 \\
Akun publik dengan jenis kelamin laki - laki & 70 \\
Akun publik dengan jenis kelamin perempuan & 90 \\
\hline
\end{tabular}

\section{B. Pra-Proses Data}

Pra-proses data yang dilakukan antara lain melakukan pelabelan untuk setiap data followings dan followers yang berhasil diambil dan modifikasi field pada array baru yang akan dipakai. Pelabelan dilakukan dengan memberikan nilai 'pk' dari username utama ke data followings dan followers, hal ini dilakukan untuk memberi informasi bahwa followings dan followers merupakan milik dari username utama. Modifikasi field merupakan perubahan nama sehingga lebih informatif dan sesuai dengan data yang akan dipakai

\section{Pembahasan}

Pembahasan mengenai nilai node dan nilai links yang mana merupakan nilai luaran untuk mendeskripsikan sociomatrix.

1. Nilai Size

Size dipakai untuk menentukan dua variabel yakni node dan text dalam menentukan seberapa besar eksistensi yang dimiliki tiap node. Nilai bulatan untuk memvisualkan tiap nodes dan besaran ukuran text username. Size yang didapatkan dari pencarian berdasarkan 'id_target' yang bernilai sama dengan ' $p k \_u s e r$ ' tiap nodes, dan memunculkan hasil seperti pada Tabel 6 .

Tabel 6 Data Size pada Nodes Collection

\begin{tabular}{lll}
\hline Size & Nilai & Jumlah \\
\hline Terkecil & 1 & 39 \\
Terbesar & 22 & 1 \\
Terbanyak & 1 & 39 \\
\hline
\end{tabular}

Adapun contoh perhitungan riil ditunjukkan seperti berikut: 
...username":"ae63ef...bd58ccea7cebc2042","size":22,"...\},

Akun ke-124 memiliki nilai size $=22$, jadi nilai untuk node akun 124:

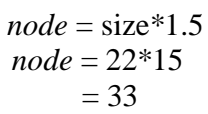

Sedangkan nilai untuk text akun 124 adalah:

$$
\begin{gathered}
\text { text }=\text { size } \\
\text { text }=22
\end{gathered}
$$

2. Nilai Value

Value dipakai untuk menentukan nilai variabel links untuk menyatakan seberapa kuat hubungan yang terbentuk antar node. Pada 'links collection', link penghubung antar node didapatkan data pada Tabel 7.

Tabel 7 Data Value pada Links Collection

\begin{tabular}{llll}
\hline Value & Nilai & Source & Target \\
\hline Terkecil & 0 & 6304602798 & 4527543293 \\
Terbesar & 287 & 248017706 & 411247021 \\
\hline
\end{tabular}

Adapun contoh riil dari penghitungan value berdasarkan rumus force-directed graph yaitu:

\{ "source":1448433148, "target":1605236345, "value":190\}

Pada contoh diatas memiliki nilai value $=190$, penghitungan nilai value sesuai force-directed graph untuk visual garis penghubungnya adalah sebagai berikut:

$$
\begin{aligned}
\text { links } & =\frac{\text { value }}{100} \\
\text { links } & =\frac{190}{100} \\
& =1.9
\end{aligned}
$$

\section{Sociomatrix dan Sociogram}

Sociomatrix menghasilkan jumlah node yang saling terhubung dan mengurutkannya berdasarkan SMA di Surabaya seperti yang ditunjukkan pada Tabel 8. Sociogram merefleksikan hubungan antar node yang sudah dibentuk berdasarkan matrix node dan matrix link sesuai dengan variabel terkait.Adapun analisis yang didapatkan dari pembahasan sociomatrix dan sociogram antara lain:

\section{Analisa Jumlah Nilai Followings dan Followers}

Analisa pertama membahas tentang faktor jumlah nilai followings dan followers. Adapun data akumulasi followings dan followers berdasarkan sekolah ditunjukkan pada Gambar 4. Data akumulasi followings dan followers tertinggi akun Instagram siswa pada sekolah MAN Surabaya dengan kode M01 (12335 followings, 16539 followers) dan nilai terendah pada sekolah SMA Luqman Hakim Surabaya dengan kode S03 (861 followings, 847 followers). 
Tabel 8 Jumlah Node dari Tiap Sekolah

\begin{tabular}{lll}
\hline Sekolah & Kode & Jumlah \\
\hline SMA Negeri 2 Surabaya & N02 / 2 & 6 \\
SMA Negeri 6 Surabaya & N06 / 6 & 11 \\
SMA Negeri 7 Surabaya & N07 / 7 & 23 \\
SMA Negeri 10 Surabaya & N10 / 10 & 4 \\
SMA Negeri 13 Surabaya & N13 / 13 & 10 \\
SMA Negeri 14 Surabaya & N14 / 14 & 6 \\
SMA Negeri 16 Surabaya & N16 / 16 & 14 \\
SMA Negeri 17 Surabaya & N17 / 17 & 7 \\
SMA Negeri 20 Surabaya & N20 / 20 & 4 \\
SMA Negeri 21 Surabaya & N21 / 21 & 5 \\
SMA YAPITA & S01 / 26 & 5 \\
SMA Muhammdiyah 2 Surabaya & S02 / 27 & 7 \\
SMA Luqman Hakim Surabaya & S03 / 28 & 4 \\
SMA IPIEMS & S04 / 29 & 6 \\
SMA 10 Muhammadiyah Surabaya & S05 / 30 & 7 \\
SMA Ta'miriyah Surabaya & S06 / 31 & 4 \\
MAN Surabaya & M01 / 51 & 6 \\
SMK Negeri 10 Surabaya & K10 / 86 & 8 \\
\hline
\end{tabular}

Pada Tabel 8, data sociomatrix bagian jumlah node dijelaskan bahwa jumlah siswa yang saling follow pada akun Instagram paling banyak berada di sekolah SMAN 7 Surabaya sebanyak 23 akun. Sedangkan terdapat empat SMA dengan nilai paling sedikit jumlah siswa yang saling follow yaitu SMAN 10 Surabaya, SMAN 20 Surabaya, SMA Luqman Hakim Surabaya, dan SMA Ta'miriyah Surabaya dengan nilai masing-masing sejumlah 4 akun.

Pada Tabel 8, tentang jumlah node tiap sekolah, memberikan asumsi bahwa banyaknya followings dan followers yang dimiliki bukan merupakan faktor penentu banyaknya hubungan pertemanan pada media sosial di suatu sekolah. Hal ini dibuktikan bahwa MAN Surabaya yang memiliki akun dengan jumlah followings dan followers terbanyak hanya memiliki 6 akun yang saling follow dengan akun siswa SMA lain di Surabaya. Adapun SMAN 7 Surabaya dengan jumlah akun yang saling follow paling banyak yaitu 23 akun yang memiliki jumlah followings dan followers sekitar 10 ribu akun Jumlah ini hamper sama dengan jumlah followings dan followers pada SMAN 10 Surabaya namun akun Instagram siswa yang saling follow hanya berjumlah 4 akun.

\section{E. Analisa berdasarkan Jenis Kelamin}

Analisa kedua tentang faktor jenis kelamin, merupakan salah satu atribut masukan pada matrix links. Adapun statistik sebaran pada jumlah akun berdasarkan jenis kelamin dibandingkan dengan links antar node untuk mengetahui persebaran tiap hubungan sosial atau pertemanan antar node berasal dari jenis kelamin yang sama (pertemanan atau saling follow sesama wanita/ pria) atau berbeda (pertemanan atau saling follow pria - wanita). Gambar 5 menunjukkan dari 160 akun terdapat 70 akun adalah 'Laki-laki' dan 90 akun 'Perempuan'.

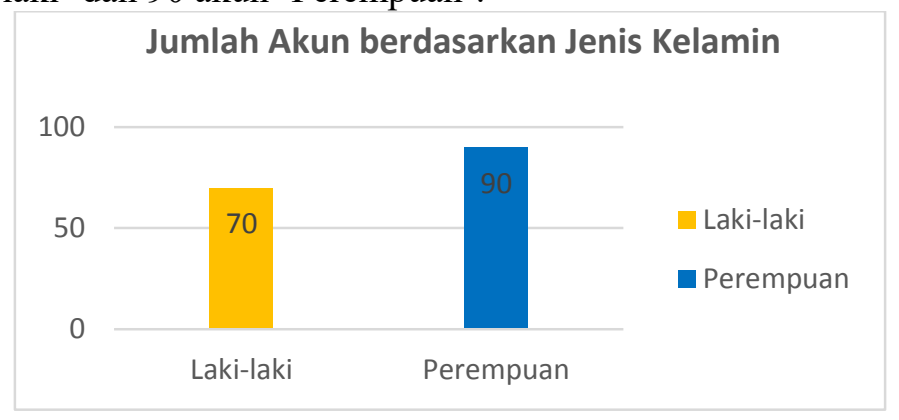

Gambar 5 Grafik jumlah akun berdasarkan jenis kelamin 


\section{Tabel 9 Satistik berdasarkan Jenis Kelamin}

\begin{tabular}{ll}
\hline Jenis hubungan & Jumlah \\
\hline Antar laki-laki & 115 \\
Antar perempuan & 289 \\
Lawan jenis & 284 \\
\hline
\end{tabular}

Tabel 9 menerangkan bahwa hubungan antar perempuan dan lawan jenis memiliki jumlah yang hampir sama. Berdasarkan data diatas bentuk analisa berdasarkan jenis kelamin yaitu pertemanan sesama jenis hanya dominan pada akun Instagram antar siswa perempuan. Sedangkan pertemanan lawan jenis jumlah atau nilainya hampir sama dengan pertemanan antar perempuan. Pertemanan antar lawan jenis yang memiliki jumlah besar dilandasi dengan umur siswa SMA tergolong remaja, dimana masa remaja adalah masa dimana mereka mengalami perkembangan psikoseksual yaitu fase usia memulai ketertarikan dengan lawan jenis [15].

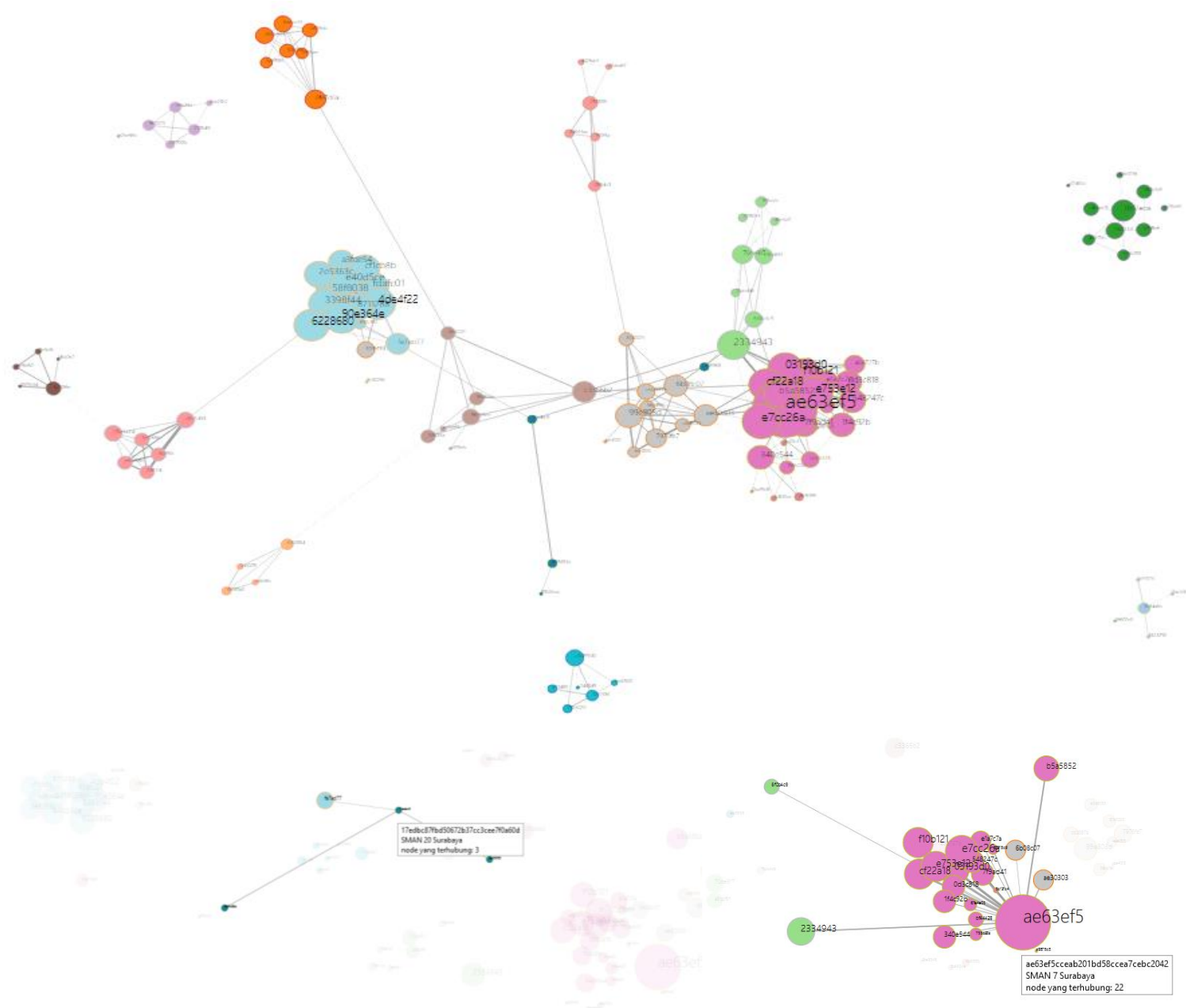

Gambar 6 Visualisasi (force directed graph) hubungan antar akun

Gambar 6 menggambarkan pola hubungan yang terbentuk antar akun siswa SMA di Surabaya. Tebal tipis garis penghubung antar nodes, besar kecil nodes dan nama akun sebagai hasil yang diberikan berdasarkan data manipulasi yang dilakukan. Tiap sekolah ditunjukkan dengan warna yang berbeda. 


\section{KESIMPULAN}

Penelitian ini menjelaskan hubungan antar pertemanan siswa SMA di media sosial Instagram. Pola petermanan yang didapat terdiri dari 1 sociogram besar meliputi 12 SMA di Surabaya dan 7 sociogram kecil. Mayoritas dari kelompok sociogram yang terbentuk berisikan siswa dari satu sekolah yang sama. Nilai node terbesar dimiliki oleh siswa SMAN 7 Surabaya dengan jumlah 22 akun yang saling follow dan nilai link terbesar dimiliki oleh siswa SMAN 7 Surabaya dengan jumlah 360 akun followings dan followers yang sama. Selain itu ditemukan bahwa pertemanan antar siswa perempuan memiliki jumlah 2,5 kali dari jumlah pertemanan antar siswa laki laki dan pertemanan antar siswa perempuan memiliki jumlah hampir yang sama dengan lawan jenis. Pada penelitian berikutnya pemberian dasar pada pembobotan berdasarkan ahli bukan dari tahap implementasi dari suatu studi kasus yang lebih menekankan pada visualisasi. Hal ini untuk penelitian lebih lanjut dengan dasar yang lebih kuat untuk mengukur hubungan berdasarkan sociomatrix.

\section{REFERENSI}

[1] Instagram, "600 million and counting," 2016. [Online]. Available: http://blog.instagram.com/post/154506585127/161215-600million.

[2] APJII, “BULETIN APJII EDISI 22 - Maret 2018,” APJII, pp. 1-7, 2018.

[3] Internet World Stats, "Digital in 2018: World's internet users pass the 4 billion mark - We Are Social," Hootsuit; We are Soc., pp. 1-18, 2018.

[4] D. Z. Grunspan, B. L. Wiggins, and S. M. Goodreau, "Understanding Classrooms through Social Network Analysis: A Primer for Social Network Analysis in Education Research," CBE—Life Sci. Educ., vol. 13, no. 2, pp. 167-178, Jun. 2014.

[5] I. Hafidz, A. R. Kautsar, T. Valianta, and N. A. Rakhmawati, "Teenstagram TimeFrame: A Visualization for Instagram Time Dataset from Teen Users (Case Study in Surabaya, Indonesia)," Procedia Comput. Sci., vol. 124, pp. 100-107, 2017.

[6] L. Manikonda, Y. Hu, and K. Subbarao, "Analyzing user activities, demographics, social network structure and user-generated content on Instagram," arXiv Prepr., vol. arXiv:1410, 2014.

[7] S.-Y. Teng, M.-Y. Yeh, and K.-T. Chuang, "Toward Understanding the Mobile Social Properties," in Proceedings of the 2015 IEEE/ACM International Conference on Advances in Social Networks Analysis and Mining 2015 - ASONAM '15, 2015, pp. 266-269.

[8] R. B. Correia, L. Li, and L. M. Rocha, "MONITORING POTENTIAL DRUG INTERACTIONS AND REACTIONS VIA NETWORK ANALYSIS OF INSTAGRAM USER TIMELINES.," Pac. Symp. Biocomput., vol. 21, pp. 492-503, 2016.

[9] W. De Nooy, A. Mrvar, and V. Batagelj, Exploratory Social Network Analysis with Pajek. Cambridge University Press, 2018.

[10] S. P. Borgatti, A. Mehra, D. J. Brass, and G. Labianca, "Network analysis in the social sciences.," Science, vol. 323, no. 5916, pp. 892-5, Feb. 2009.

[11] B. Carolan, Social Network Analysis and Education: Theory, Methods \&amp; Applications. 2455 Teller Road, Thousand Oaks California 91320 United States: SAGE Publications, Inc., 2014.

[12] D. L. Hansen and M. A. Smith, "Social Network Analysis in HCI," in Ways of Knowing in HCI, New York, NY: Springer New York, 2014, pp. 421-447.

[13] M. S. Z. Rizvi, "Game of Thrones Force Directed Graph," 2019. [Online]. Available: https://bl.ocks.org/mohdsanadzakirizvi/6fc325042ce110e1afc1a7124d087130. [Accessed: 05May-2020].

[14] S. Tridetti, "Social network analysis : detection of influencers in fashion topics on Twitter," University of Liège, 2016.

[15] E. Triyanto, "The Puberty Experience of Adolescent Fenomenology Study in Purwokerto," J. Ners, vol. 5, no. 2, pp. 147-153, 2010. 